\title{
EL ECO EN LA PRENSA Y DOCUMENTACIÓN DIPLOMÁTICA ESPAÑOLAS DE LOS PROCESOS A LOS RESPONSABLES DE LA DERROTA GRIEGA EN ASIA MENOR
}

Pedro Álvarez de Frutos

I.E.S. «MARIANO QUINTANILLA» de Segovia. España

Resumen: Un grupo de oficiales da un golpe de estado en Atenas en septiembre de 1922 tras la catástrofe del ejército griego en Asia Menor. El Rey fue expulsado y se inició un juicio contra los que fueron considerados responsables del desastre. Seis ministros y militares fueron condenados a muerte y fusilados, y el príncipe Andrés, hermano del Rey, fue condenado al destierro y degradación militar.

La Embajada de España en Atenas siguió estos acontecimientos, y la prensa española, además, comparó el desastre de Asia Menor con el de Annual.

Palabras clave: Catástrofe - Asia Menor - Golpe de Estado - Prensa Española

\section{THE ECHO IN THE PRESS AND SPANISH DIPLOMATIC DOCUMENTATION OF THE PROCESSES RESPONSIBLE FOR THE GREEK DEFEAT IN ASIA MINOR}

Abstract: A group of officers gave a coup d'état in Athens in September 1922 after the catastrophe of the Greek army in Asia Minor. The King was deported and s lawsuit began against those considered responsible of that disaster. Six ministers and army officers were found guilty, condemned to death and executed, while Prince Andrew, the King's brother, will be condemned to exile and military dishonour.

The Spanish Embassy in Athens closely followed these events and the Spanish press compared the Asia Minor disaster with the previous one occurred in Annual, Morocco.

Keywords: Catastrophe - Asia Minor - Coup d'État - Spanish Press

Recibido: 27.11.2014 Aceptado: 22.01.2015 
Pedro Álvarez de Frutos: El eco en la prensa y documentación diplomática españolas...

Correspondencia: Pedro Álvarez de Frutos. pedroalvarez.name@hotmail.es

Licenciado en Historia. Profesor I.E.S. "MARIANO QUINTANILLA” de Segovia. Plaza Morería 10, 3º. 40002 Segovia.

\section{\NTRODUCCIÓN}

\subsection{Grecia}

El presente trabajo está asociado a la actualidad por las nuevas y recientes valoraciones que se han hecho sobre los "negros días de 1922 con el juicio y la ejecución de los seis....” y la petición realizada, recientemente, por algunas fuerzas políticas ${ }^{1}$ y particulares $^{2}$ para que se repita el juicio que llevó a la ejecución de los responsables de la tragedia de Asía Menor en 1922.

Aquel juicio y las posteriores ejecuciones, desde entonces y hasta hoy, ponen en tela de juicio la política de los partidos "burgueses" sobre la catástrofe de Asia Menor. ¿Quiénes fueron los responsables? ¿Únicamente los ocho juzgados y los seis fusilados, o toda la clase política venizelista (liberal de centro-centroizquierda) y antivenizelista (popular de centro-derecha y derecha)? Ésto se preguntaba el exprimer ministro de Nueva Democracia, Georgios Ralis, nieto de Dimitrios Ralis, uno de los muchos primeros ministros de aquel periodo tan agitado, en un artículo aparecido en el semanal de historia y en el que también se pregunta "si Venizelos quería o no la ejecución" ${ }^{3}$. En

${ }^{1}$ Por ejemplo, las opiniones de Georgios Karatzaferis, líder del partido de derechas, Laikos Ortódoxos Synagermós en To Vima, 8 de octubre de 2011, "me neo Gudí apileí o Karatzaferis".

${ }^{2}$ La sentencia de aquel juicio fue recurrida por Mijalis Protopapadakis, nieto de uno de los ejecutados, y el 20 de octubre de 2010 el Tribunal Supremo griego la anuló. Con motivo de este proceso salió a la luz el libro de Nicos TSAGUAS, I athoosi ton eksi ke $i$ anatropi tis historias, Atenas: ed. Gkovotsi, 2012.

${ }^{3}$ Semanal Historiká del diario Elefcerotipía, v.6, 25 de noviembre de 1999. Sobre el "nuevo juicio" Historia Iconografimeni, v.521, noviembre de 2011, homenaje a la campaña militar en Asia Menor 1919-22 y en particular la aportación de Dimitris Filippís «"diki” gia ena stijiomeno orama», págs. 75-80. 
cualquier caso, continúa "fue una solución muy cómoda encontrar a seis Ifigenias". Para la historiografía griega, el juicio es un capítulo de la historia negra del país que se estudia casi por separado y no necesariamente sólo como epílogo de la catástrofe ${ }^{4}$.

El juicio de los seis representa la segunda gran intervención del Ejército griego en la política y en la historia contemporánea del país (la primera tuvo lugar en 1909 con la revolución militar de Gudí). Con miles de refugiados, presos de pánico, llegando a las islas del Egeo y al continente, y con el Ejército desmoralizado por la derrota y sin los apoyos de Francia e Inglaterra, un grupo de oficiales a cuya cabeza se sitúa Nicólaos Plastiras tomaron el poder ${ }^{5}$. Los acontecimientos de Grecia que aquí tratamos tienen como telón de fondo dos enfrentamientos: el nacional griego y el internacional.

La política griega mantenía un enfrentamiento larvado desde la Primera Guerra Mundial. Durante esta guerra, el rey Constantino, respaldado por su familia, la élite política de comienzos de siglo y parte del Ejército, apoyó a los Imperios Centrales, mientras que Venizelos, en unión de la burguesía liberal y de la otra parte del Ejército, fue aliadófilo, lo que llevó a que Grecia tuviera dos gobiernos, uno en

${ }^{4}$ Sobre la historiografía griega nos limitamos a citar el más antiguo Alexandros KOTZIÁS, Ta foverá documenta. I diki ton eksi. Epilogos sto Gudí, Atenas: ed. Fitrakis, y los estudios recientes de Georgios K. STEFANAKIS, I diki ton okto ke i ektélesi ton eksi, Atenas: ed. Savalas, 2010, y del periodista y exministro Gianis KAPSÍS, I diki ton eksi. 60 meres pu álaksan mia jora, Atenas: ed. Livanis, 2012. Este acontecimiento tuvo impacto en la literatura (ver, por ejemplo, la obra teatral sobre el juicio de Vasilis Vasilikós). Respecto de la historiografía extranjera, monografía de referencia publicada sobre el juicio de los seis no hay en otras lenguas, únicamente existe bibliografía sobre Grecia en Asia Menor dentro de la cual se estudia también el juicio. Nos limitamos a citar el estudio de Michael Llewellyn SMITH, Ionian Vision: Greece in Asia Menor 1919-1922, London: Hurst \& Co, 1998 (el cap.14 en la traducción griega que hemos consultado).

${ }^{5}$ Sobre las intervenciones del ejército cf. Thanos Veremis, The Greek Military in Politics From Independence to Democracy, 1997, y Dimitris Filippis Profasismós, ekfasismós, pseudofasismós, Salónica: University Studio Press, 2010. Cf. también las referencias diplomáticas que se pueden localizar como tesis doctoral en el Centro de Documentación de Tesis Doctorales de Grecia, como Dimitris FILIPPÍS, SJesis Eladas-Italías 1919/201940 ke i emplokí tis Ispanías, Atenas: Pantion Panepistimion, 2005, en http://phdtheses. ekt.gr/eadd/?locale=el 2012. 
Salónica, dirigido por Venizelos -septiembre de 1916- y avalado por los aliados, que llegaron a entrar en El Pireo para mantener la neutralidad del Gobierno de Atenas y "obligaron a Constantino a abdicar en 1917"', lo que irritó a los griegos porque vieron en esta acción una ingerencia inadmisible; y otro en Atenas, monárquico de tendencia germanófila. Acabada la guerra, el partido de Venizelos perdió las elecciones legislativas griegas (noviembre de 1920) y los gobiernos monárquicos del rey Constantino decidieron mantener la campaña militar en Asia Menor, pero el impulso político del Gran

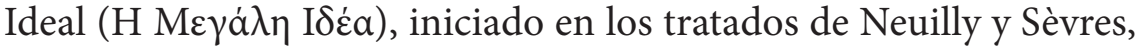
que pretendía anexionar a Grecia toda la Tracia hasta Constantinopla (H Пó $\lambda$ ), y la antigua Jonia, se había debilitado.

Ilustra especialmente bien esta cuestión el discurso de Asquith, líder del Partido Conservador, durante la campaña electoral inglesa. Según su expresión, «el tratado de Sèvres está tan muerto como el de Utrecht» por los cambios producidos que describe con estas palabras:

"Como consecuencia de la acción kemalista han desaparecido la Armenia independiente, la Jonia griega, la zona de influencia francesa en Cilicia y la italiana en Adalia. Desde el día 9 de septiembre las tropas turcas están en Esmirna, y el día 23 del mismo mes los aliados se vieron obligados a prometer a Turquía la restitución de Constantinopla y de la Tracia oriental hasta el río Maritza. Quedan en suspenso la libertad de los Estrechos, el problema de la Tracia occidental, las pretensiones turcas sobre Alejandreta y Mosul, y sobre las islas Imbros, Ténedos, Mitilene y Chios; la protección de la minoría cristiana y la abrogación de las capitulaciones» ${ }^{7}$.

${ }^{6}$ E. MALEFAKIS, «Grecia y España: ¿hasta qué punto historias paralelas?», en: Grecia y España. Los confines de Europa, Madrid: Oficina de Prensa de la Embajada de Grecia Universidad Autónoma, 2002, Pág. 60.

${ }^{7} A B C$, 21 de noviembre de 1922, pág.19: «Boletín del día. La Conferencia de Lausana y el Problema de Oriente». También hace un análisis de la situación de cada uno de los problemas pendientes. 
El marco internacional se mueve dentro de los intereses económicos, políticos y estratégicos de los aliados, no necesariamente coincidentes entre Inglaterra y Francia, y menos aún con Rusia, que desconfían del Estado turco, germanófilo durante la guerra mundial, que no garantizaba los intereses comerciales y estratégicos occidentales en la zona. A este respecto, Agustín Hamon culpa a:

«Las clases burguesas occidentales (que) han preparado poco a poco esta Revolución -se refiere a la turca- haciendo un tratado de paz unilateral, injusto y antiigualitario y subyugando a los griegos, contaminados del delirio de grandezas ... Gracias al oro ruso y a las armas francesas los turcos vencen a Grecia, y los capitalistas franceses se regocijan y hacen burla a sus colegas ingleses que habían apostado por la pérdida de los turcos» ${ }^{8}$.

El 22 de julio de 1920 comenzó el ataque griego en Asia Menor. Tras los primeros avances del ejército griego hacia el interior de Anatolia, cambió la situación y el 30 de agosto de 1922 las tropas turcas rompieron las líneas griegas. El 8 de septiembre, Esmirna fue evacuada y el día 9 sucedió lo que los griegos llaman la Catástrofe de

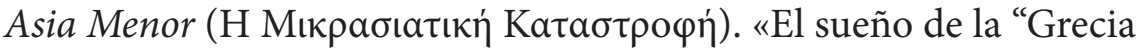
de los dos continentes y los cinco mares" se acabó para siempre»". En Grecia, la derrota propició un golpe de Estado. Jóvenes oficiales de grado intermedio, algunos de orientación política venizelista, descontentos con la situación militar por la derrota, y con el Ejército en disolución, decidieron formar un Comité Revolucionario. Los principales miembros de este comité fueron el capitán del buque Lemnos, Dimitrios Focás, y los coroneles Stilianos Gonatás y Nicólaos Plastiras. El golpe militar se materializó el 11 de septiembre de 1922 y supuso la abdicación del rey Constantino I, que abandonó definitivamente el país el 30 de septiembre ${ }^{10}$, la llegada al trono de su

\footnotetext{
${ }^{8}$ El Socialista, 7 de diciembre de 1922, pág. 1: «La revolución turca» [Agustín Hamon].

${ }^{9}$ Cf. MALEFAKIS, art. cit., pág. 60.

${ }^{10}$ Así lo comunica el encargado de negocios en Atenas, Inclán, al ministro de Estado en telegrama fechado el 1 de octubre de 1922. Archivo Ministerio Asuntos Exteriores y Cooperación (en adelante AMAE), Correspondencia (Grecia), leg. 1605. En él se dice que
} 
hijo Jorge II y la formación de un gobierno controlado por militares, que inició el juicio de los que consideraron responsables del desastre militar. Bajo la firma de Fabra, el diario El Sol informó que el Comité Revolucionario había publicado el día 18 de octubre un mensaje dirigido al pueblo en el que hacía constar que «la revolución no iba encaminada únicamente a alejar del Trono a Constantino, sino al grupo político y militar que había puesto al Rey por encima de la patria, abolido las libertades del pueblo y provocado los recientes desastres» (se refiere al de Asia Menor) ${ }^{11}$. El 19 de octubre de 1922 se formó una comisión de investigación del desastre presidida por Theodoros Pángalos, que acusó de traición a Dimitrios Gúnaris, exprimer ministro, Petros Protopapadakis, Nicólaos Stratós, primer ministro durante algunos días de mayo de 1922, Georgios Baltadsís ${ }^{12}$ y Nicólaos Theotokís, junto con los militares Georgios Jadzianestis, Jenofonte Stratigós ${ }^{13}$ y Michael Gudás. Cuatro días después, el 23 de octubre, se anunció que los acusados serían juzgados por un tribunal militar. El juicio comenzó el 13 de noviembre, presidiendo el tribunal de diez oficiales el general Aléxandros Othoneos. El día 22 del mismo mes se habría «celebrado una gran reunión...sin distinción de partido, para manifestar su adhesión a los fines de la revolución... de todas las Corporaciones obreras, Asociaciones, Ligas y Sociedades» ${ }^{14}$. El 27, el mismo diario informó

junto al exrey Constantino han embarcado en el trasatlántico griego Patrís, escoltado por el torpedero Príncipe Paul, antes Diádoque, la exreina Sofía, la princesa Catalina y el príncipe Nicolás, "quedando en Grecia el ex Rey que usa el título de Conde de Acharnon". (Nota: Ha sido imposible comprobar a que rey se refiere. Sus antecesores Jaime I y Alejandro I, abuelo y hermano, respectivamente, habían muerto, y su padre había salido de Grecia).

${ }^{11}$ El Sol, 19 de octubre de 1922, pág. 1: "La revolución no se hizo sólo para derribar a Constantino". [Fabra].

${ }^{12}$ El Sol, 19 de octubre de 1922, pág. 5, añade al exministro Vozakis: "Ex ministros griegos acusados" [Fabra]. El día 28 este diario añadiría entre los detenidos al expresidente del Consejo Sr. Colageropoulos, EL SOL, 28 de octubre de 1922, pág. 5: "Detención de un ex presidente del Consejo" [Fabra]; y el 16 de noviembre daba la noticia de la detención, el día anterior, del general Pallis, exjefe del Estado Mayor del ejército de Asia Menor: El Sol, 15 de noviembre de 1922, pág. 1.

${ }^{13}$ El Sol, 24 de octubre de 1922, pág. 5: Según una nota de Atenas del día 22, se había ordenado el encarcelamiento de este general por considerarlo el principal responsable del desastre. [Fabra].

${ }^{14}$ El Sol, 24 de octubre de 1922, pág. 5: «Manifestación griega en apoyo de la revolución» [Fabra]. 
del descubrimiento de un complot contrarrevolucionario en el que estarían implicados el ya exrey Constantino, el príncipe Andrés y el general Metaxás ${ }^{15}$. El 24 de noviembre dimitió el Gobierno, formándose inmediatamente uno nuevo con Gonatás como primer ministro y Pángalos como ministro de Defensa.

El tribunal militar dictó sentencia condenatoria el 28 de noviembre y, a media mañana, los condenados fueron trasladados a la colina de Gudí, a las afueras de Atenas, y fusilados.

El día 29 el diario $A B C$ publicó el siguiente texto:

"La sentencia estaba prevista desde que se inauguró el proceso, puesto que los militares revolucionarios se hallaban decididos a infligir un castigo ejemplar a quienes consideran como culpables del mayor de los desastres que sufrió el helenismo desde la toma de Bizancio"16.

La familia real embarcó en el trasatlántico griego Patrís, que fue escoltado por el torpedero Príncipe Pablo, antes Diádoco.

\subsection{España}

En lo que se refiere a España, existe un cierto paralelismo entre el desastre griego en Asia Menor (agosto-septiembre de 1922) y el desastre español en Annual (julio de 1921), como se ha puesto de manifiesto en numerosas ocasiones. Así, el diario El Sol publicó un editorial ${ }^{17}$ que subrayaba los paralelismos y divergencias entre estos dos acontecimientos y su tratamiento posterior:

«Alguna vez se ha señalado el paralelismo entre el desastre griego y nuestro desastre de Annual. No son pocos los rasgos

${ }^{15}$ El Sol, 27 de octubre de 1922, pág. 1: «Complot contrarrevolucionario en Grecia» [Fabra]. ${ }^{16}$ ABC, 29 de noviembre de 1922, pág. 15: «Boletín del Día. Seis Ejecuciones».

${ }^{17}$ El Sol, 2 de noviembre de 1922, pág. 5: «Responsabilidades... en Grecia». Manifestaciones de este tenor se repiten los días 4, 18 y 19 de noviembre: Editoriales «La impunidad en Marcha», «Las actuaciones judiciales sobre el desastre de Melilla», "Grecia y España», págs. 5,2 y 1 respectivamente. 
Pedro Álvarez de Frutos: El eco en la prensa y documentación diplomática españolas...

comunes que dan una fisonomía semejante a ambos sucesos: la misma indeferencia popular hacia la empresa de conquista; iguales avances impremeditados; el mismo desconocimiento de la situación. Pero el paralelismo termina en el momento de la catástrofe. Mientras aquí se incoa un expediente, allí se hace una revolución. No es que nos agrade una revolución... en Grecia están acusados de alta traición tres ministros del Gobierno que sufrió el desastre: el presidente Gúnaris, el ministro de la Guerra Theotokís y el de Negocios Extranjeros -ahora Asuntos Exteriores- Baltazzi. En Grecia no hay expedientes filantrópicos ni inhabilitaciones, como en España».

Y el diputado Cambó llegó a comparar Esmirna con Melilla, Angora con Axdir y a Abd-el-Krim con Kemal Pachá ${ }^{18}$.

Para gran parte de los españoles, Grecia fue un ejemplo de lo que debería ocurrir cuando hay un fracaso tan enorme como el de Annual. Como ejemplo y al margen de los diarios citados en el título, el periódico de Madrid La Voz lo expresa así:

«Grecia, estos días, nos está dando un bello ejemplo de lo que debe hacer un pueblo cuando sus clases directoras le llevan al fracaso deshonroso. ¿Vale España menos que Grecia?» ${ }^{19}$

El desastre de Annual se produce dentro del primer periodo del reinado de Alfonso XIII, que se inició en 1902, cuando con tan sólo16 años fue declarado mayor de edad, y terminó en 1923 con el establecimiento de la dictadura de Primo de Rivera. Este periodo se caracterizó por la existencia de una crisis política permanente debida a las continuas intervenciones políticas del rey al margen del papel mediador que le adjudicaba la constitución; por la división de los

${ }^{18}$ Diario de sesiones del Congreso de los Diputados núm. 80, junio de 1922, pág. 3222. Segundo turno de intervención del diputado Cambó sobre Presupuesto de gastos de la sección 13: "Acción en Marruecos".

${ }^{19} \mathrm{La} \mathrm{Voz}, 21$ de noviembre de 1922, pág. 3: «Es preciso hacer justicia ejemplar con los responsables». Perteneció al mismo grupo que El Sol, liberal y regeneracionista, pero tuvo un carácter más popular. 
partidos del "turno" debido a la desaparición de sus líderes históricos, lo que les impidió alcanzar mayorías estables para sus gobiernos y malogró el intento regeneracionista del sistema de la Restauración del liberal José Canalejas; y por el desarrollo de las clases urbanas que apoyarán opciones políticas de oposición con orientaciones nacionalistas, republicanas y de izquierda.

El texto del diario del rey ilustra muy bien la situación:

«En este año me encargaré de las riendas del estado, [...] yo me encuentro el país quebrantado por nuestras pasadas guerras, que anhela por un alguien que lo saque de esa situación. La reforma social a favor de las clases necesitadas, el ejército con una organización atrasada a los adelantos modernos, la marina sin barcos, la bandera ultrajada, los gobernadores y alcaldes que no cumplen las leyes, etc. En fin, todos los servicios desorganizados y mal atendidos. Yo puedo ser un rey que se llene de gloria regenerando a la patria, cuyo nombre pase a la Historia como recuerdo imperecedero de su reinado, pero también puedo ser un rey que no gobierne, que sea gobernado por sus ministros y por fin puesto en la frontera» ${ }^{20}$.

Así, las luchas sociales se avivaron como consecuencia de la industrialización y el desigual reparto de los beneficios de la neutralidad durante la I Guerra Mundial. Éstas culminaron en la Semana Trágica de Barcelona y la huelga general de 1917. El Ejército, humillado por la derrota de 1898 y objeto de las críticas de los partidos de la oposición, se encontraba dividido porque los oficiales "peninsulares" protestaban por los rápidos y, a veces, inmerecidos ascensos de los "africanistas". Todo ello condujo a la creación de las Juntas de Defensa. Setenta diputados y senadores de la Lliga Regionalista, republicanos, socialistas e incluso algún liberal constituyeron en Barcelona la Asamblea Nacional de Parlamentarios, una Asamblea que pidió un cambio de gobierno y la convocatoria de Cortes Constituyentes. Y, finalmente, el problema de

${ }^{20}$ Diario personal Alfonso XIII (1902), en: Carlos SECO SERRANO: «La España de Alfonso XII», Cuadernos de Historia 16, núm. 98, Madrid, 1985. 
Pedro Álvarez de Frutos: El eco en la prensa y documentación diplomática españolas...

Marruecos originado en la sublevación de las tribus del norte contra la ocupación colonial española principalmente, concretada en varios tratados que se iniciaron en 1907.

España había establecido relaciones diplomáticas con el nuevo Estado griego en $1834^{21}$, pero fue tras la derrota de España en 1898 frente a EE.UU. y la liquidación de los restos de su Imperio cuando España comenzó a reactivar su política exterior con una orientación netamente europea, es decir, durante el reinado de Alfonso XIII. «En este contexto deben entenderse las relaciones hispano-helénicas durante la primera década del siglo $\mathrm{XX}{ }^{22}$. Aun siendo conscientes, tanto la monarquía como los gobiernos, de los cambios producidos en la esfera internacional tras la Guerra Mundial, «no tuvieron un programa de política exterior planificado y coherente ante la nueva situación, con iniciativas, decisiones y soluciones adecuadas», privilegio reservado a las grandes potencias, y su orientación principal fue «buscar la afinidad con Francia e Inglaterra y no comprometerse en alianzas con grandes potencias extranjeras capaces de obligar al país a intervenir en conflictos extraños a la nación» ${ }^{23}$; opinión que queda corroborada por la del ministro de Estado cuando dice: «¿Qué cosa más natural que marchar de acuerdo con Inglaterra y Francia? Y si entre ellas surge discordia de la que podamos apartarnos, de la que podamos evitar que nos alcancen las consecuencias ¿qué cosa más natural también que tomar esta actitud?» ${ }^{24}$.

${ }^{21}$ AMAE, Correspondencia (Grecia), leg. 1601: Despacho dirigido por el encargado de negocios de España en Grecia, Mariano Montalvos, al ministro de Estado, Atenas, 22 de enero de 1835. Sobre la categoría de la representación española en Grecia, ver el diario de sesiones del Congreso de los Diputados núm. 52, lunes, 5 de junio de 1922, pág. 2140. Intervención del ministro de Estado sobre Presupuesto de la sección $2^{2}$ : de las obligaciones de los Departamento ministeriales, Ministerio de Estado.

${ }^{22}$ M. MORCILLO, Las relaciones diplomáticas entre España y Grecia a través de sus fuentes documentales (1834-1935), pág. 6 (http://www.ahistcon.org/docs/murcia/contenido/ pdf/15/matilde_morcillo_rosillo_taller15.pdf. 2012).

23 A. NIÑO, «Política de alianzas y compromisos coloniales para la Regeneración internacional de España, 1898-1914», en: J. TUSELL-J. AVILÉS-R. PARDO, La política exterior de España en el siglo XX, Madrid: Biblioteca Nueva, 2000, págs. 47-48.

${ }^{24}$ Contestación del ministro de Estado al diputado Barcia sobre política exterior de España. Diario de Sesiones, Congreso de los Diputados, núm. 3835, Sesión del 18 de julio de 1922, pág. 3852 . 
Curiosamente, Grecia y España, junto con Bélgica y Brasil, fueron designados miembros del Consejo de la Sociedad de Naciones a un tiempo y por iniciativa de Estados Unidos y Gran Bretaña hasta la primera elección de representantes ${ }^{25}$. Que España fuera neutral y que fuera una potencia media sin intereses de ningún tipo en la zona quizá fue lo que le permitió representar a turcos en Grecia y a griegos en Turquía ${ }^{26}$.

La Embajada de España en Atenas siguió e informó de estos acontecimientos al entonces Ministerio de Estado de España, y la documentación que existe en el Archivo del Ministerio de Exteriores y Cooperación unida a la proporcionada por los diarios $A B C, E l$ Socialista y El Sol ha servido de base para este estudio.

\section{2.- EL JUICIO A LOS SEIS}

\subsection{Las acusaciones}

El diario $\mathrm{El} \mathrm{Sol}^{27}$ publicó un resumen del informe del Comité Revolucionario en el que se hacían constar las acusaciones a los

${ }^{25}$ J.C. PEREIRA CASTAÑARES - J.L. NEILA HERNÁNDEZ, La España de Alfonso XIII en el sistema internacional de posguerra (1919-1931) (http://www.historiacontemporanea. ehu.es/s0021-con/es/contenidos/boletin_revista/00021_revista_hc34/es_revista/ adjuntos/34_06.pdf 2012).

${ }^{26}$ La representación de los intereses turcos en Salónica se puede ver en el despacho núm. 27 del cónsul de España en Salónica de 26 de septiembre de 1922, AMAE, Correspondencia (Grecia), leg.1605, pág. 1, $\$ 2$ : «Por estar nosotros encargados de la protección de los intereses otomanos en Salónica y su distrito». Que España representara los intereses griegos en Turquía durante la guerra aparece en el telegrama núm. 891, cifrado clave 301, de 2 de diciembre de 1922, del embajador de España en París al ministro de Estado de España (AMAE, Correspondencia [Grecia], leg. 1605), y en el telegrama del Ministerio de Estado de España al embajador en Atenas de 26 de diciembre de 1922, (AMAE, Correspondencia [Grecia], leg.1605, núm. 30). Con posterioridad, según el despacho núm. 15, de 1 de febrero de 1923, del embajador de España en Atenas a la Subsecretaría del Ministerio de Estado, en cumplimiento de la R.O. de 21 de enero pasado, se comunica el acuerdo respecto a la forma de «envío de la correspondencia oficial con el consulado general griego en Constantinopla» (AMAE, Correspondencia [Grecia], leg. 1605.

${ }^{27}$ El Sol, 10 de noviembre de 1922, Pág. 5: "Las acusaciones del Comité revolucionario griego" (Radio). El informe se hizo público en Atenas el día 8. 
responsables del desastre en Asia Menor y los nombres de aquellos que debían comparecer ante el Consejo de Guerra: Gúnaris, Baltadsís, Stratigós, Protopapadakis, Gudás, Theotokís, Jadsianestis y Stratós. Se aparta al rey del juicio porque «según el Derecho constitucional es irresponsable» y se enumeran hasta quince causas de la acusación de carácter político -nacional e internacional, territorial, económico y estratégico-. No obstante, el 7 de diciembre este mismo diario publicó una nota según la cual el Comité Revolucionario acordó que también «fuera juzgado en Consejo de guerra...(el que fuera) alto comisario de Grecia en Asia Menor, general Sterguiadis, a quien se acusa de tener gran parte en las responsabilidades por el desastre». Como dicho general había huido, sería "condenado en rebeldía" 28. Con posterioridad, hubo otras detenciones: Tsaldaris ${ }^{29}$ y Tertipis $^{30}$, que fueron ministros del Gabinete de Gúnaris, pero los procesos a los responsables de segundo grado serían sobreseídos y comparecerá únicamente ante un consejo de guerra el general Constantinópulos ${ }^{31}$.

Al parecer, los acusados habían convocado un plebiscito para decidir el regreso del rey Constantino haciendo caso omiso de una nota aliada de 8 de diciembre de 1920 -supuestamente contraria a su celebración-. "Ocultaron al pueblo su respuesta»" ${ }^{32}$. Ocultaron que Francia e Inglaterra ${ }^{33}$ habían declarado varias veces que «Grecia

${ }^{28}$ El Sol, 7 de diciembre de 1922, pág. 5: «El alto comisario en Asia Menor será condenado en rebeldía». [Fabra].

${ }^{29}$ Debe tratarse de Panagiotis Tsaldaris, líder del Partido Popular, que en 1921-22 fue ministro de transportes de Gúnaris y, después, primer ministro en la década de los años 30 (1932-33, 1933-35). Era el gran adversario de los venizelistas.

${ }^{30}$ Debe tratarse de Konstantinos Tertipis, ministro de Agricultura en el gabinete de Gúnaris de 1921.

${ }^{31}$ El Sol, 17 y 22 de diciembre de 1922, págs. 1 y 5: «Detención de dos ex ministros griegos». [Fabra] e «Índice de noticias», respectivamente.

${ }^{32}$ R. Glogg dice: «Gran Bretaña, Francia e Italia expresaron su oposición al retorno del Rey pero, en el plebiscito que se celebró al respecto, evidentemente amañado, 999.960 votos fueron a favor de la restauración de la monarquía y sólo 10.383 en contra» (Historia de Grecia. Cambrige: University Press, 1998, trad. de Helena Aixendri, pág. 99).

${ }^{33}$ El profesor Malefakis opina que a pesar de los logros griegos durante la Primera Guerra Mundial y del éxito diplomático en París, «los aliados dieron el visto bueno a que Grecia se anexionara las regiones helénicas de Turquía» (op. cit., pág. 60). 
no podría contar con ningún apoyo mientras que Constantino permaneciera en el Trono. Los acusados no aconsejaron al rey la necesidad de abdicar, ni siquiera dimitieron ellos, continuaron ocultando al pueblo la verdad» y comunicaron a los aliados que «el 90 por 100 de los votantes lo habían hecho a favor de la vuelta del ex rey». Por otra parte, «toleraron un Gobierno camarilla compuesto por el príncipe Nicolás Strip Dousmani y otros que, por medio de asesinatos, amenazas y agresiones a los ciudadanos pacíficos, sembró el terror en el país». En la esfera internacional, además de lo arriba relatado sobre los aliados, se los acusó de impedir que el presidente Ralis «se pusiera al frente de la representación de Grecia, y rechazaron los servicios de Venizelos para representar a los griegos irredentos ${ }^{34}$.

Las acusaciones de carácter territorial se refieren a la no adopción de «las medidas necesarias para anexionarse el norte del Epiro y el Dodecaneso», y redujeron al mínimo las reivindicaciones nacionales del Tratado de Sèvres, confiaron la mediación a las potencias y les otorgaron carta blanca. Las acusaciones económicas se centraron en la ocultación de una nota aliada del 6 de diciembre de 1920, «referente al bloqueo económico de Grecia en el caso de que regresara Constantino», en el «acuerdo con Inglaterra renunciando a los créditos prometidos por las potencias» y las recompensas pecuniarias «a favor de los amotinados, de los desertores y otros». Las acusaciones sobre la estrategia se concretan en que «acordaron conferir al ex Rey, que era un factor irresponsable, el mando efectivo del Ejército» en contra de la opinión del comandante en jefe competente, «nombraron comandante general del Ejército al general Jadsianestis, que era público y notorio estaba desequilibrado», y «colocaron al frente de las grandes y pequeñas unidades militares cuadros ineptos; alejaron a los oficiales experimentados, para favorecer a oficiales desacreditados». Finalmente, el citado resumen

\footnotetext{
${ }^{34}$ En agosto de 1916 militares venizelistas favorables a la Triple Entente se levantaron en Salónica contra al Gobierno monárquico. Los aliados, entre otras acciones, reconocieron el Gobierno de Venizelos y se aseguraron la neutralidad del Gobierno monárquico de Atenas mediante el desembarco de soldados franceses e ingleses en El Pireo, cf. CLOGG, op. cit., pág. 94.
} 
Pedro Álvarez de Frutos: El eco en la prensa y documentación diplomática españolas...

dice que «la culpabilidad de los acusados aparece de un modo palpable por su insistencia en sostener en el trono a Constantino, insistencia que provocó finalmente la catástrofe nacional».

También en España se culparía al rey del desastre de Annual. D. Miguel de Unamuno escribía en El Socialista:

«Suele decirse, en los momentos críticos de la historia de la Monarquía, si es el rey el culpable de los derrumbes y las catástrofes, o son los políticos que le rodean. Tal el caso de Grecia. Y cuando se dice los que le rodean, se quiere decir aquellos de que se rodea $\aleph^{35}$.

\subsection{El juicio y las sentencias}

El lunes día 13 de noviembre comenzó en Atenas el juicio ${ }^{36}$. Al día siguiente, la defensa alegó la "incompetencia del Tribunal" poniendo "en duda la legalidad de su constitución". Después, Gúnaris apeló a la voluntad nacional ${ }^{37}$. El general Anastasios Papoulas ${ }^{38}$, exgeneralísimo de las tropas de Asia Menor, declaró el 15 de noviembre que «la responsabilidad integra de lo ocurrido era únicamente imputable al anterior Gobierno y al Consejo de Guerra, en particular, así como la iniciativa de las tres ofensivas y de la marcha sobre Angora». Añadió, que «no había tenido noticia de la nota enviada por los gobiernos aliados advirtiendo a Grecia de los peligros que podría traer consigo

${ }^{35}$ El Socialista, 1 de diciembre de 1922, pág. 1: «Crisis suprema».

${ }^{36} \mathrm{El} \mathrm{Sol,} 14$ de diciembre de 1922, pág. 5: «Índice de noticias».

${ }^{37}$ El Sol, 14 de diciembre de 1922, pág. 5: «El desastre griego en oriente». [Radio].

${ }^{38}$ Este general fue nombrado comandante en jefe de las tropas griegas en 1920, durante la Guerra Greco-Turca de 1919-1922. Sus ofensivas sobre Anatolia no tuvieron éxito, a pesar de que para la segunda recibió refuerzos hasta alcanzar los 100,000 hombres. Fue derrotado en la primera y segunda batalla de Inonu en enero y 28-30 de marzo de 1921. Perdió el puesto de comandante en jefe por orden del rey Constantino. Terminó su vida política como venizelista. Con posterioridad a los fusilamientos fue acusado y encarcelado con los generales Dumis, y Valetas. Cf. El Sol, 1 de diciembre de 1922, pág. 5: «Después de los fusilamientos». El día 3 desmentiría el encarcelamiento del general Dumis, pero ahora con el nombre de Dusmanis. En consecuencia, no queda claro si es el mismo general o un error. 
la restauración en el trono de Constantino» ${ }^{39}$. El día 17 declararon como testigos varios oficiales. Éstos manifestaron «la propaganda derrotista y las pésimas condiciones en que efectuaba el abastecimiento de las tropas, desmoralizadas por las deficiencias que se observaban». El diputado Ralis, hijo del exministro, declaró que «el Gobierno griego había dado seguridades, en enero de 1921, al Gobierno británico de que el ejército heleno era suficientemente capaz de liquidar el asunto de Asia Menor en el espacio de tres semanas ${ }^{40}$.

Con anterioridad a que se conociera la condena a muerte de los dirigentes políticos y militares del Desastre en Asia Menor, se produjo la dimisión del Gobierno ${ }^{41}$. Según el embajador de España en Atenas, la dimisión se debió a que quizás no querían aparecer «aceptando la responsabilidad de ciertas sentencias» (lógicamente, se refiere a las de muerte de los responsables políticos y militares del desastre). Los ministerios del nuevo Gobierno fueron ofrecidos a políticos civiles, pero éstos no aceptaron, por lo que se constituyó un Gobierno que podría llamarse militar porque de él «toma la Presidencia el jefe del Comité Revolucionario y miembros del mismo se encargan de varias carteras, entre ellas la de Guerra y la de Marina». El Ministerio de Asuntos Exteriores se le ofreció al antiguo ministro de Grecia en Berna, Aléxandros Baltadsís ${ }^{42}$.

La opinión del embajador en relación con la formación de este nuevo Gobierno a instancias del Comité Revolucionario es que se había formado así porque «es opinión bastante generalizada que unas elecciones hechas ahora serían una derrota para el Comité Revolucionario y su conducta, pues el pueblo no ha visto con buenos

${ }^{39}$ El Sol, 16 de noviembre de 1922, pág. 1: «La derrota griega en oriente» [Fabra].

${ }^{40} \mathrm{El} \mathrm{Sol}, 18$ de noviembre de 1922, pág. 1: «El proceso contra los responsables -declaraciones de testigos-» [Fabra].

${ }^{41}$ Despacho núm. 95, 27 de noviembre de 1922, del embajador de España en Atenas para el ministro de Estado de España. (AMAE, Correspondencia [Grecia], leg. 1605). El Sol, 26 y 28 de noviembre de 1922, da cuenta de la dimisión y de la constitución del nuevo Ministerio sin opinión alguna.

${ }^{42}$ Para esta información el embajador se apoya en el testimonio que le ofrece el corresponsal del Daily News, porque la Legación española aún no había recibido la comunicación. 
Pedro Álvarez de Frutos: El eco en la prensa y documentación diplomática españolas...

ojos la marcha del rey Constantino ni el procesamiento de todos los políticos que han sido acusados». A este respecto, se censura al Comité: que no era constitucional, que tampoco lo era la formación del tribunal que juzgaba a los encausados ${ }^{43}$ ni el procedimiento seguido. Sin embargo, según el citado periodista, los del Comité argumentaban que los acusados no podían ser juzgados por la Cámara de Diputados porque, hecha la revolución, debería haber habido nuevas elecciones, pero este procedimiento retrasaría mucho el juicio.

El 28 de noviembre se conoce la sentencia a muerte contra Gúnaris, Baltadsís, Theotokís, Protopapadakis, Stratós y Jadsianestis ${ }^{44}$, que estuvo encabezada por la fórmula «En nombre de S.M. Jorge II», quien comentó posteriormente al embajador español que se había enterado tan sólo media hora antes de que fueran fusilados los ministros y el general en jefe ${ }^{45}$. Además de la pena de muerte, el Tribunal revolucionario condenó a los políticos ejecutados a las siguientes multas: Gúnaris, 200.000 dracmas; Stratós, 355.000; Protopapadakis, 500.000; Baltadsís y Theotokís, un millón de dracmas cada uno. El almirante Gudás, exministro de Marina, fue condenado a la multa de 200.000 dracmas $^{46}$.

La ejecución se produjo a las once de la mañana de ese mismo día 28 en la colina de Gudí. Algunos días después el diario El Sol

${ }^{43}$ A este respecto, Richard Clogg en su Historia de Grecia pág. 102, n. 32, dice así: «El Consejo de Guerra estuvo presidido por el general Othoneos y, dado que él y los demás oficiales habían sido escogidos por el comité revolucionario, existían pocas dudas sobre el veredicto final de lo que fue esencialmente una farsa judicial».

44 Telegrama núm. 27, cifrado clave 301, 28 de noviembre, enviado a las 15:00 (AMAE, Correspondencia [Grecia], leg. 1605). En él se cita a los cuatro primeros y se añade "y otros dos". El embajador olvidó incluir entre los fusilados, según El Sol, al general de división Jadsianestis, y los otros dos debieron ser el almirante Gudás y el general Stratigós condenados a cadena perpetua y degradación. Cf, El Sol, 29 de noviembre de 1922, pág.1: «Ayer fueron fusilados seis ex ministros» [Fabra]. El Sol, 3 de diciembre de 1922, pág. 5 publica imágenes de los fusilados.

${ }^{45}$ Despacho núm. 98, 2 de diciembre de 1922, del embajador de España en Atenas para el ministro de Estado de España (AMAE, Correspondencia [Grecia], leg. 1605).

${ }^{46}$ ABC, 30 de noviembre de 1922, pág. 21: «Los responsables del Desastre Griego». El cambio de una dracma en aquel momento equivalía a 20 céntimos de peseta. 
publicó el relato del corresponsal en Atenas de Le Petit Parisien, que transcribo íntegramente por su especial dramatismo ${ }^{47}$.

«La sentencia les fue comunicada a los seis condenados a las ocho y media de la mañana por el comisario de la Revolución Neocosmos Grigoriades. Al acabar éste la lectura de la sentencia, advirtió que se cumpliría inmediatamente, y les indicó que, si querían, podían dar el último abrazo a sus familiares. Todos aceptaron, y, al salir de la prisión el comisario, se dejó entrar a las familias.

A la media hora se condujo a los condenados al patio de la prisión, y el generalísimo fué degradado.

Un instante más tarde, alguien vió acodado en una ventana al señor Baltazzai. "Tenía el aspecto completamente tranquilo." Se supo después que durante la entrevista de los condenados y sus parientes, éstos, engañados por una generosa ilusión, pretendieron que no se llevara a cabo el fusilamiento. Sin embargo, a esa hora estaban ya tomadas todas las decisiones, y lo irrevocable iba a cumplirse.

Las tropas, el prefecto de Policía y algunos magistrados se trasladaron al lugar de la ejecución, que fué un campo desolado en las afueras, lleno de detritus y de latas de conservas, que parece el seco lecho de una torrentera.

Era una mañana lluviosa, sombría y glacial.

Las tropas que formaron el cuadro eran originarias de la Tracia. El pelotón que tenía que efectuar la ejecución estaba formado por treinta y seis hombres.

Poco después de las once, los asistentes oyeron sonar las bocinas de los autos y el retemblar de los motores. Eran tres. El primero y el último llevaban soldados armados. En el de en medio iban los condenados.

${ }^{47}$ El Sol, 13 de diciembre de 1922, pág. 5: «Cómo se llevó a cabo el fusilamiento de los ex ministros griegos». Por ser una cita se mantiene la puntuación, ortografía originales y la transcripción de los nombres griegos que hizo el autor y el diario. 
El primero en descender fue Stratos, y se volvió para dar la mano a Gounaris. Una espantosa palidez había en el rostro del antiguo presidente del Consejo, y, no obstante, marchó con paso firme y rechazó a Baltazzi, que también acudió para sostenerle.

Les siguieron los otros tres, y pronto formaron un grupo negro en medio del rectángulo de las tropas, bajo la lluvia que no cesaba de caer.

El ex ministro de la Guerra, Theotokis, se aproximó a un soldado inmóvil.

-¡Que se acabe esto pronto!- exclamó.

El Sr. Stratos sacó una pitillera y se la ofreció a un oficial, con estas palabras:

-Dile a mi hijo que le pido de todo corazón que no se ocupe nunca de política, y que guarde esto en recuerdo de mis últimos instantes.

Entonces, Baltazzi limpiaba su monóculo, empañado por el frío, y, al verlo, Protopapadakis hizo lo mismo con sus gafas. En cuanto al general, temblaba, y se veía que las lágrimas rodaban por su rostro.

Todo esto, que parece tan largo, no duró más de un instante.

Los seis hombres fueron colocados ante los ejecutores.

Durante la noche se había construido una trinchera, y ante ella un parapeto.

Detrás de ese parapeto, que les cubría las piernas y el vientre, fueron alineados los sentenciados. Se encontraban en el orden siguiente, de izquierda a derecha: Theotokis, Baltazzi, Stratos, Gounaris, Protopapadakis y Hadjianesti. Todos mostraban en ese supremo instante un rostro tranquilo, excepto el general, presa de "tics" nerviosos cada vez más acelerados.

Un segundo más tarde, y se oyó una voz:

¡¡Pyr! ... (¡Fuego!)

Los seis condenados, con un solo movimiento, desparecieron detrás del parapeto.

En ese instante cesó la lluvia." 
El embajador Vallín atribuirá al coronel Plastiras, jefe del Comité Revolucionario, al que califica de "sanguinario" y "especie de dictador", el haber dictado la "orden de ejecutar la sentencia"48.

El diario El Sol dedicó dos de las ocho columnas de su primera página a la noticia sobre los fusilamientos ${ }^{49}$, y El Socialista, bajo el expresivo título «En Grecia no es como aquí», publicaba la noticia del fusilamiento $y$ un comentario en el que relacionaba el tiempo transcurrido entreloshechos juzgados y la sentencia $y$ el procedimiento seguido para ello con lo ocurrido en España respecto del desastre de Annual, para concluir:

«La opinión pública española $[. .$.$] se pregunta$ [...] si en verdad en nuestro

\section{GRECIA Y ESPAÑA, POR BAGARÍA. ${ }^{50}$}

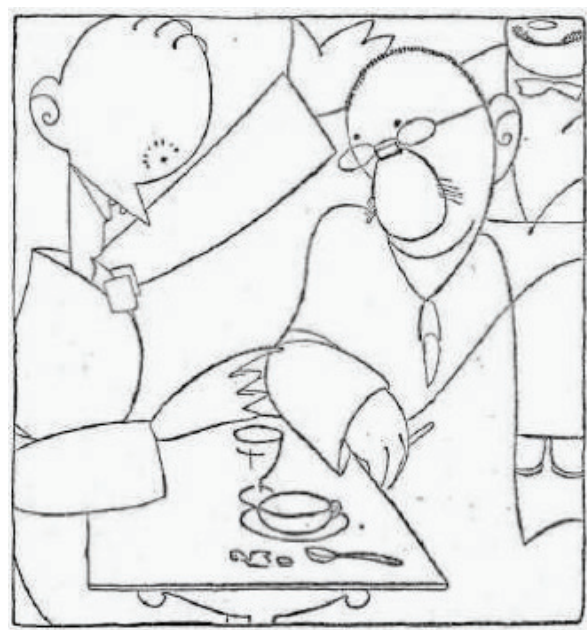

${ }_{-i}$ Ha visto usted qué barbaridad hacen esos griegos? -Sí, hombre, sí. Como que más vale ser tabonero en España que ministro en Grecia. país ni siquiera se podrá procesar a los señalados como culpables [...] Si Grecia es el país de la tragedia, España parece ser el pueblo del sainete ${ }^{51}$.

El día 23, el mismo diario socialista publicó una nota sobre las declaraciones del teniente Socufóculos, de la marina griega, que dijo haber estado presente durante la ejecución, según las cuales los relatos

\footnotetext{
${ }^{48}$ Telegrama número 30, cifrado clave 239, 2 de diciembre de 1922, del embajador de España en Atenas al ministro de Estado (AMAE, Correspondencia [Grecia], leg. 1605).

${ }^{49} \mathrm{El} \mathrm{Sol,} 29$ de noviembre de 1922, pág. 1. «Ayer fueron fusilados seis ex ministros». [Fabra].

${ }^{50}$ Ilustración de Bagaría publicada en El Sol, 29 de noviembre de 1922, pág. 1.

${ }^{51}$ El Socialista, 29 de noviembre de 1922, pág. 1.
} 
Pedro Álvarez de Frutos: El eco en la prensa y documentación diplomática españolas...

que circulaban acerca de esos momentos aran falsos y que «los ex ministros condenados a la última pena fueron a la muerte con firmeza, bravura y serenidad verdaderamente admirables» ${ }^{52}$. El día 30, en la misma publicación Indalecio Prieto decía: «Y como aquí no se ha hecho, ni se hace, ni se hará la revolución, habremos de contentarnos con..."Eso de Grecia está bien; lo mismo se debía hacer en España»"53.

\subsection{La actividad diplomática}

La posición política de la Legación de España en Atenas, que comienza a relatar estos hechos en el despacho de 23 de noviembre, jueves, de $1922^{54}$, fue seguidista de las posiciones de otras embajadas, adhiriéndose, como la mayoría de las legaciones, a los movimientos realizados por los representantes de Gran Bretaña e Italia. En el despacho citado se anuncia que toda la Cámara de Diputados cree que el juicio se dará por terminado antes del sábado siguiente y detalla todas las actividades que se han realizado para evitar el fusilamiento de los miembros del Gobierno del rey Constantino, porque los representantes extranjeros, según el ministro pleniponteciario embajador-, don Cristobal Vallín, sabían que era intención de los revolucionarios fusilar al Gobierno responsable del desastre. El embajador inglés había dirigido "una nota muy enérgica" al ministro griego de Asuntos Exteriores, Nicólaos Politis ${ }^{55}$, con el fin de impedir el fusilamiento. Tal nota fue contestada verbalmente por Politis, que le aseguró que «en caso de sentencia capital, ésta no sería ejecutada y se conmutaría la pena». Pero, posteriormente, Politis le pidió al embajador británico que le relevara de la promesa, pues no creía poder cumplirla. El embajador italiano, por su parte, hizo una gestión verbal y el resto de los embajadores se unieron a las gestiones de los mencionados. Ciertamente, Mussolini aprovechó los

${ }^{52}$ El Sol, 24 de diciembre de 1922, pág. 5: «Los ministros griegos fusilados». [Fabra].

${ }^{53}$ El Socialista, 30 de noviembre de 1922, Pág. 1 "Desde el escaño. Impresiones parlamentarias".

${ }^{54}$ Despacho núm. 93, 23 de noviembre de 1922, del embajador de España en Atenas para el ministro de Estado de España (AMAE, Correspondencia [Grecia] leg. 1605).

${ }^{55}$ Nicólaos Politis (1872-1942) fue ministro de Exteriores del gobierno Plastiras en 1922 y a continuación representante diplomático de Grecia en la Comunidad de Naciones. 
acontecimientos griegos para afianzarse en el poder y continuar con el dominio italiano en el Dodecaneso ${ }^{56}$.

Ahora bien, esta intervención británica fue calificada posteriormente "de torpe" por Venizelos, delegado griego en Lausana y fino diplomático. De esa intervención dijo que «había precipitado la catástrofe... (porque el embajador de Inglaterra) pretendió imponerse violenta y airadamente provocando el enojo del gobierno militar revolucionario" ${ }^{57}$. La única excepción correspondió al representante de Francia, que se abstuvo porque, «según dicen, manifestó que obraba de acuerdo con las instrucciones de su Gobierno».

En este despacho, el embajador español también expone que la impresión de todos sus colegas era pesimista respecto de la sentencia. En previsión de que fueran condenados a muerte «parte o todos los ministros acusados, así como los jefes militares», siguiendo el ejemplo del representante de Rumanía, varios embajadores prepararon una petición al Comité Revolucionario solicitando la conmutación de la pena capital. A la vista de la petición que le hizo el representante de Rusia, y viendo que ya lo habían firmado los representantes antes

${ }^{56} \mathrm{Al}$ dictador italiano le interesaba poner de manifiesto la anarquía en Grecia y compararla con la estabilidad italiana, debida a él, por supuesto. Por otra parte, los dos acontecimientos que permitieron a Mussolini convertir en permanente el, hasta entonces, transitorio dominio italiano en el Dodecaneso fueron la ejecución de los Seis y, al año siguiente, el accidente de Yannina con la muerte del General italiano Telini, jefe de la comisión responsable de trazar la frontera entre Grecia y Albania. Este último acontecimiento dio a Mussolini el pretexto para invadir y ocupar Corfú en septiembre de 1923. Tras la intervención internacional, Grecia indemnizó a Italia y, así, las tropas italianas aceptaron abandonar la isla. Cf. D. FILIPPÍS, Prefascismos, fascismós y pseudofascismos, Salónica: University Studio Press, 2010, págs. 103-107 y 120-134.

${ }^{57}$ Telegrama núm. 4, cifrado clave 265, de 2 de diciembre, de Reynoso, delegado de España en Lausana, al ministro de Estado de España (AMAE, Correspondencia [Grecia], leg. 1605). Cuando el ministro británico en Lausana, Lord Curzon, reprochó a Venizelos «no haber intervenido eficazmente cerca del Gobierno de su país para evitar la ejecución de los ex ministros». Venizelos le contestó «que le extrañaba mucho la ingerencia de Inglaterra en asuntos interiores de Grecia, [...] (porque) Grecia era un país libre y no una colonia inglesa», cf. El Sol, 1 de diciembre de 1922, pág. 5: «Agria entrevista de Lord Curzon y Venizelos». 
citados, además de los de Holanda y Suecia, entre otros, y «del fin humanitario que se persigue», el embajador español prometió firmarla, aunque para ello no tenía permiso del Ministerio de Estado.

Días más tarde ${ }^{58}$, el embajador expresa su temor de "que haya ciertas - no especifica cuales- represalias si los acusados llegan a ser ejecutados». En todo caso, dice, «el porvenir se presenta muy sombrío», y también expone que se ha desistido de presentar al Comité Revolucionario la petición solicitando la conmutación de la pena, incluida una petición verbal, porque los representantes de Serbia y Polonia «han recibido instrucciones de sujetar su conducta a la de Francia», el representante de Brasil, en su opinión, se habría abstenido y el de Italia estaba ausente en Lausana. También comunica que en caso de sentencia capital y de que ésta se ejecutara, el representante de Gran Bretaña dejaría Atenas, pero que a éste le costaba trabajo creer «que esta gente ${ }^{59}$ llegase a ocasionar la ruptura de relaciones con Inglaterra» y que, según conversación con el corresponsal del Daily News, tras la nota del embajador británico el Comité Revolucionario había ofrecido al embajador de Inglaterra «que los que fuesen sentenciados no serían ejecutados y se les dejaría marchar de Grecia siempre que Gran Bretaña garantizase que éstos no volverían a hacer política ni ocuparse de los asuntos de este país». Inglaterra no quiso suscribir esta condición.

El embajador Vallín comunicó al Ministerio de Estado, mediante telegrama $a^{60}$, las sentencias de muerte, y ese mismo día envió un despacho ${ }^{61}$. En éste muestra su desconfianza de la transmisión de su telegrama anterior, porque el corresponsal del Daily News no

\footnotetext{
${ }^{58}$ Despacho núm. 95, 27 de noviembre de 1922, del embajador de España en Atenas para el ministro de Estado de España, (AMAE, Correspondencia [Grecia], leg. 1605).

${ }^{59}$ No queda claro si la expresión "esta gente" corresponde al embajador inglés o español, pero resulta algo despectiva e impropia de un diplomático.

${ }^{60}$ Telegrama núm. 27, cifrado clave 301, 28 de noviembre de 1922, enviado a las 15:00 (AMAE, Correspondencia [Grecia], leg. 1605).

${ }^{61}$ Despacho núm. 97, 28 de noviembre de 1922 (AMAE, Correspondencia [Grecia], leg.1605.
} 
había conseguido que cursaran el suyo, pero, según podemos ver, se transmitió a las 15:00, habiendo sido enviado al telégrafo a las 14:45. En él confirma el contenido del telegrama anterior, es decir, la muerte de los condenados, a los que ahora añade al antiguo ministro Nicólaos Stratós y "al que fue general en jefe"; que la sentencia fue ejecutada a las 11:00 de la mañana; que Gúnaris, "enfermo gravísimo de tifus, fue sacado de la cama para ser llevado a la muerte, y como temían, sin duda, que se muriese antes de ser fusilado, se hizo algo para hacerlo revivir»; comenta y también pone de manifiesto, según le ha dicho su colega belga, la presencia de ánimo Gúnaris que, a pesar de su estado, «había manifestado...que sabía a lo que le llevaban y les declaró que no temieran que se muriese antes, pues viviría lo suficiente para (que) fueran los revolucionarios los que lo matasen». El despacho también hace referencia a la "sorpresa" que había supuesto la condena y ejecución del ministro de Asuntos Exteriores, Baltadsís, porque siempre se le había considerado francófilo y el embajador de Francia había dicho a varios colegas que no sería condenado. También atribuye cierta responsabilidad en el resultado final del proceso a la "actitud de Francia”, sin precisar cual, aunque manifiesta que varios colegas acreditados en Atenas (tampoco precisa quienes) así lo consideran. $\mathrm{Y}$ parece -aunque esto lo transmite con reservas- que el embajador francés Marcilly había telegrafiado a su Gobierno para «que procurase que el de Inglaterra enviase para reemplazar a Linddley -que se ausentaba esa misma noche- otro ministro de sentimientos más francófilos». El mismo despacho considera que la situación en que queda Grecia, al parecer compartida por muchos de los embajadores, es muy grave y difícil, porque con la ruptura con Inglaterra pierde «el único punto de apoyo posible que acaso le quedaba para intentar salir de sus apuros más apremiantes». El diario El Sol incluiría en su edición del día 29 la retirada del embajador inglés en Atenas, las reacciones de la prensa británica, Daily Press y Evening News y otros, que condenaban el fusilamiento y aludían a la posible pérdida del apoyo financiero, y publica una biografía de Gúnaris ${ }^{62}$.

${ }^{62}$ El Sol, 29 de noviembre de 1922, pág.1: «Ayer fueron fusilados seis ex ministros» [Fabra]. 
En relación con la actitud de la prensa inglesa, el embajador en Londres envía, el día 30, dos telegramas al ministro de Estado español $^{63}$. En ellos relata que varios periódicos de Londres, los más allegados al Gobierno, pero también algunos liberales: a) «censuran como grave error diplomático la actitud del gobierno de Gran Bretaña hacia la reciente ejecución en Atenas por estimar que dicha intervención excede a la corrección que debe conservarse respecto a asuntos internos de otras naciones»; b) estigmatizan los fusilamientos como reprobables y en extremo censurables; c) ponen de manifiesto que estos hechos colocan a Grecia en situación delicada frente a Gran Bretaña en la conferencia de Lausana, siendo, como es, su único apoyo. Esta situación, según el segundo telegrama, se vio reflejada en la relación "de tal frialdad", según la prensa, respecto de Venizelos, delegado de Grecia en Lausana, que parecía probable que éste se retirara de la Conferencia. Según el embajador en Londres, éste es también el criterio del público británico en general.

El mismo día y los siguientes la actividad diplomática fue intensa. Así, el ministro de Estado español pide al embajador en París mediante telegrama ${ }^{64}$ que se interese por conocer la actitud del Gobierno francés respecto de Grecia y la resolución de Inglaterra respecto de la ruptura de relaciones. El mismo día, el embajador de España en La Haya, Méndez Vigo, comunica ${ }^{65}$ al Ministerio de Estado que el jefe de política del Ministerio de Asuntos Exteriores de Holanda le ha dado instrucciones a su embajador en Madrid «para conocer (el) criterio (del) Gobierno de Su Majestad sobre el fusilamiento».

Durante el mes de diciembre, el diario El Sol siguió publicando noticias. El día 1 nos hacía saber que el rey de Grecia, habiendo fracasado sus gestiones para evitar los fusilamientos, «ha ofrecido de nuevo al Comité Revolucionario su abdicación, a la que seguiría,

${ }^{63}$ Telegramas núm. 543 y 544, cifrado clave 241, 30 de noviembre de 1922, del embajador en Londres al ministro de Estado (AMAE, Correspondencia [Grecia], leg. 1605).

${ }^{64}$ Telegrama núm. 536, cifrado clave 221, 30 de noviembre de 1922, del Ministerio de Estado de España al embajador en París (AMAE, Correspondencia [Grecia]], leg. 1605).

${ }^{65}$ Telegrama núm. 128, cifrado clave 301, 30 de noviembre de 1922, del embajador en La Haya al ministro de Estado. AMAEC, (AMAE, Correspondencia [Grecia]], leg. 1605). 
naturalmente, el abandono del país... pero el Gobierno lo ha confinado en el palacio real»; las reacciones de censura de Estados Unidos por las ejecuciones, y del Vaticano, que «intervendrá cerca del Gobierno de Atenas para impedir nuevas ejecuciones»; de Italia, de la que, dice, «se asegura que, de acuerdo con los Gobiernos aliados, ...va a enviar navíos de guerra al Pireo» y cuyo Gobierno anuncia oficialmente que «se niega a reconocer al gobierno actual de Atenas», y de Il Corriere della Sera, que pide «ante el Tribunal Internacional de Justicia de la Haya» que los responsables de los fusilamientos «sean condenados a muerte» ${ }^{66}$, y de Inglaterra tras retirar a su embajador en Atenas y su temor por el príncipe Andrés ${ }^{67}$.

El día 2 de diciembre Camba publicó en su columna un comentario mordaz, que merece ser leído, sobre la actitud del embajador británico en Atenas y lo relaciona con la investigación del desastre de España en Annual. En ella se hace eco de la publicación en el diario parisino Le Matin de despachos de carácter secreto «que establecen los estímulos sucesivos que el Gobierno de Atenas recibió del Sr. Lloyd George (primer ministro inglés) para emprender

CARTA DE ROMANONES, por BAGARÍA ${ }^{69}$

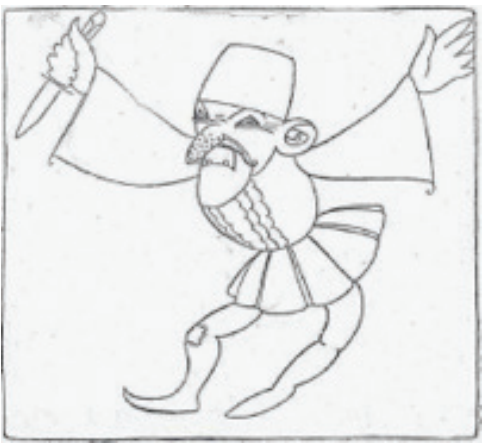

Eres griego y no te creo.

Ilustración alusiva a España con motivo de Grecia. la campaña en Asia Menor: de la opinión, a este respecto, del Foreign Office a través del diario Evering News, según la cual esos "documentos secretos [...] pertenecen a la Historia, y [...] muertos [...] los interesados, lo mejor es guardar silencio»; y de la creación de un Gabinete venizelista sin Venizelos ${ }^{68}$.

${ }^{66}$ Llama poderosamente la atención la actitud de la Italia fascista, que condena los fusilamientos pero no ve su propia violencia y, también, la actitud condescendiente de las potencias europeas que no hacen ningún asco a las intervenciones de Italia.

${ }^{67}$ El Sol, 1 de diciembre de 1922, pág.5: «Después de los fusilamientos» [Fabra].

${ }^{68}$ El Sol, 2 de diciembre de 1922, pág.1: «Crónicas de Camba» y «La situación en Grecia». El mismo diario publicó el día 5, pág. 5, un suelto según el cual el diario británico Daily 
El día 3 el diario El Sol incluía la dimisión del jefe de la Misión especial griega en Washington que, en su día, había enviado Venizelos, porque «no podía continuar a las órdenes de un régimen que se había atraído por su crueldad la indignación del Mundo» ${ }^{70}$ y una pequeña nota según la cual comunicaban desde Atenas que continuaba la indignación popular contra el gobierno por los fusilamientos, que en Patras y Misolongui habían estallado graves desórdenes y en Corfú habían izado la bandera inglesa (esta noticia respecto de Patras y Corfú fue desmentida el día $5^{71}$ ). Se hacía también eco de unas declaraciones del exrey Constantino hechas en Palermo, según las cuales «el acto -fusilamiento- del gobierno revolucionario es incalificable. Otros pueblos -sin duda se refiere a España- han padecido fracasos análogos sin que hayan sido fusilados sus ministros» ${ }^{72}$. No opinaba de igual modo el diputado socialista, Indalecio Prieto, quien en su discurso en relación con el desastre de Annual $^{73}$ dice que «una catástrofe como la de Annual, en los pueblos que tienen vitalidad, se liquida con una revolución que derriba el régimen causante de la misma», en clara alusión a Grecia.

\section{3.- EL JUICIO AL PRÍNCIPE ANDRÉS}

El príncipe Andrés -casado con la princesa Alicia de Battenberg, bisnieta de la reina Victoria de Inglaterra, y padre del duque de

Chronicle había sacado un artículo «evidentemente inspirado por Lloyd George, en el que pide que se alimente el nacionalismo turco porque "el turco es esencialmente un individuo que debe ser gobernado y no puede, por consiguiente, construir un estado sólido"».

${ }^{69}$ Ilustración de Bagaría publicada en el diario El Sol, 2 de diciembre de 1922, Pág.1.

${ }^{70}$ El Sol, 3 de diciembre de 1922, pág. 5: «Protesta contra el gobierno -dimisión de un enviado diplomático-», «Indignación popular -desórdenes en varias ciudades-» [Fabra] $\mathrm{y}$ "Consternación de la familia real griega». [Radio].

${ }^{71}$ El Sol, 3 de diciembre de 1922, pág..5: "La salida de Grecia" [Fabra].

${ }^{72}$ El Sol, 3 de diciembre de 1922, pág. 5: «Consternación en la familia real griega. Ruego al Rey de Italia». [Radio].

${ }^{73}$ Defensa del voto particular de la minoría socialista en el Congreso de los Diputados.

Discurso publicado en El Socialista entre los días 22 al 29 de noviembre de 1922, pág. 4; y más adelante dirá: «Las responsabilidades que el futuro parlamento pueda atraer están ahí; la otra, desgraciadamente, no la podemos sancionar: es la que un pueblo vital hace efectiva con una revolución». Este texto corresponde a la publicación del día 28. 
Edimburgo, casado con Isabel II de Inglaterra-, nació en Atenas el 20 de de enero de 1882 y fue coronel de Caballería ${ }^{74}$. Durante las operaciones militares en Asia comandó el Segundo Cuerpo de Ejército y, tras la derrota, fue detenido en Corfú y encarcelado en Atenas en la antigua residencia del príncipe Nicolás ${ }^{75}$ para después ser juzgado por insubordinación y condenado a destierro perpetuo con degradación militar.

\subsection{Acusaciones y sentencia}

El diario $E l$ Sol informó el día 1 de diciembre de que el sumario del príncipe Andrés había pasado a dictamen del Gobierno ${ }^{76}$. En él se le acusa de "desobedecer las órdenes del generalísimo, desobediencia que originó el fracaso de las operaciones» ${ }^{77}$. El proceso comenzó el sábado, 3 de diciembre y el acta de acusación, según el diario El Sol, puntualizaba $^{78}$ :

«Cuando el ejército helénico detuvo su avance de Sangarios en Kalo Crotto, para avituallarse, el comandante en jefe ordenó al príncipe, que mandaba el segundo Cuerpo de ejército, en vista de ciertos movimientos del enemigo que hacían prever su intención de emprender una ofensiva, que atacara a los turcos, cuya orden se negó a cumplir».

El príncipe, que «vestía de paisano»-llamativo siendo un proceso militar- y que «al contestar a las preguntas del presidente parecía muy conmovido y falto de esa entereza y energía naturales en un general llamado para justificar su actuación en la guerra», declaró en su defensa que «en la orden de ataque dada al segundo Cuerpo se añadía que éste debía esperar un aviso del tercer Cuerpo», aviso que no llegó. Fueron citados como testigos los generales Papulas y Dusmanis, que

${ }^{74} \mathrm{El} \mathrm{Sol}, 1$ de diciembre de 1922, pág. 5: «Los responsables del desastre griego» [Fabra].

${ }^{75}$ El Sol, 27 de octubre de 1922, pág. 1: «El Príncipe Andrés, detenido» [Radio].

${ }^{76}$ El Sol, 1 de diciembre de 1922, pág. 5: «Sumario contra el Príncipe Andrés».

${ }^{77}$ El Sol, 3 de diciembre de 1922, pág. 5: «Los responsables del desastre griego» [Fabra].

${ }^{78} \mathrm{El} \mathrm{Sol}, 5$ de diciembre de 1922, pág. 5: «El Príncipe Andrés degradado y extrañado a perpetuidad» [Oficial]. 
no acudió, y el coronel Saríyannis, subjefe de Estado Mayor del general Papulas. El coronel puso de manifiesto la indisciplina del príncipe al exponer que el comandante en jefe ordenó al segundo Cuerpo «que atacara encarnizadamente porque el enemigo concentraba fuerzas frente al tercer Cuerpo», y que en lugar de ejecutar la orden contestó que «era imposible a causa de los potentes trabajos de defensa del enemigo», lo que supuso «que fuera reemplazado el jefe del Estado Mayor del segundo Cuerpo». El coronel Saríyannis añadió que «si el príncipe hubiera cumplimentado la orden, todas las probabilidades indican que la batalla de Sangarios hubiera sido ganada, puesto que el tercer Cuerpo conservó sus posiciones a pesar de los contraataques del enemigo». Abundando en la indisciplina, el coronel añadió que el príncipe había amenazó con dimitir si se insistía en la ejecución de la orden, orden que, en opinión del general Papulas, hubiera cumplido cualquier otro que no fuera el príncipe, y «reconoció que el príncipe no fue destituido por su calidad de hermano del rey».

La sentencia, acordada "por unanimidad", se produjo en la noche del 2 al 3 del diciembre o en la mañana del 3. En ella se le declaró "culpable de desobediencia y abandono del puesto ante el enemigo» y se reconocían "circunstancias atenuantes vista su inexperiencia para el mando de grandes unidades». Se le condenó a la pena de destierro y «destronamiento perpetuo (y) degradación militar» ${ }^{79}$. Llamó la atención de la prensa «la honda indiferencia manifestada por el pueblo [...] no había frente al parlamento grupo alguno ${ }^{80}$. Según el embajador español en Atenas, el mismo día 3 por la tarde el príncipe Andrés llegó al puerto de Falero acompañado por el coronel Pángalos y la princesa Alicia entre otros ${ }^{81}$, y allí embarcó en

\footnotetext{
${ }^{79}$ ABC, 5 de diciembre de 1922, pág. 21: «El Principie Andrés, Degradado y Deportado»; telegramas núms. 32 y 899 de los embajadores de España en Atenas y París respectivamente, de 3 de diciembre, al ministro de Estado de España.

${ }^{80}$ El Sol, 3 de diciembre de 1922, pág. 5: «Los responsables del desastre griego]. [Fabra].

${ }^{81}$ Despacho núm. 99 del embajador de España en Atenas, 5 de diciembre de 1922, para el ministro de Estado de España. El diario El Sol de 5 diciembre de 1922, pág. 5 apunta que embarcó en el buque Calypso y que el comendador Kennworthy preguntó al gobierno británico «en virtud de qué órdenes el crucero Calypso fue enviado a Grecia para
} 
un buque de guerra británico hacia Brindisi para continuar después hasta Inglaterra. El decreto que hizo efectiva la sentencia se publicó el día 5 de diciembre y la noticia apareció en el diario El Sol del día $6^{82}$.

\subsection{La actividad diplomática}

Si respecto del juicio a los responsables del Desastre de Asia la diplomacia española fue seguidista de la actividad de otras embajadas, con ocasión del juicio al príncipe Andrés tomó iniciativas y tuvo posiciones políticas más comprometidas. La Embajada de España no sólo estuvo más atenta a este proceso que al de los generales y ministros, sino que alertó al Ministerio de Estado de la posible sentencia condenatoria a muerte del príncipe y, para evitarla, propuso una gestión personal del rey de España cerca del presidente del Consejo de Ministros de Grecia y de Venizelos ${ }^{83}$.

La iniciativa fue inmediatamente puesta en práctica y produjo una intensa actividad diplomática de la Embajada de España en Atenas. Ésta buscó el apoyo de otras embajadas - Rusia y Rumaníay el Ministerio de Estado español pidió y logró la intervención de Francia. Al tiempo, otros países -Inglaterra y la Santa Sede-, motu proprio o por encargo, también intervinieron.

Enterado el Ministerio de Estado del problema, contestó al día siguiente poniendo de manifiesto la preocupación del rey de España por su familia griega. Al tiempo, señala la implicación del Gobierno griego en los juicios de los que hablamos:

«Sírvase V.E. visitar ese señor presidente Consejo Ministros y decirle, á nombre de Su Majestad que, ignorando si puede comunicar libremente con el Rey de Grecia, acuda á V.E. con

recoger al príncipe Andrés, desterrado, y cuánto costará a Inglaterra el viaje»; cf. El Sol, 6 de diciembre de 1922, pág. 5: «Degradación del Príncipe Andrés de Grecia» [Radio].

${ }^{82}$ El Sol, 6 de diciembre de 1922, pág. 5: «Degradación del Príncipe Andrés de Grecia» [Fabra].

${ }^{83}$ Telegrama núm. 28, cifrado clave 232, 30 de noviembre de 1922, del embajador en Atenas al Ministerio de Estado de España (AMAE, Correspondencia [Grecia], leg. 1605). 
Pedro Álvarez de Frutos: El eco en la prensa y documentación diplomática españolas...

el ruego que formula, no solo á nombre Nación española sino de sentimientos humanitarios que está seguro de ver unánimemente compartidos, de que al apreciar los actos del Príncipe Andrés sean juzgados con la mayor benignidad $\mathrm{y}$ en ningún caso se le imponga pena que pueda de nuevo impresionar honda y tristemente al mundo civilizado, aun no repuesto de la hondísima sensación que hubieron de producir las recientes ejecuciones realizadas en esa capital ${ }^{84}$.

Ese mismo día el ministro de Estado pone al corriente a don Francisco Reynoso, delegado en Lausana, del telegrama enviado a Atenas y le ordena practicar idéntica gestión cerca de Venizelos ${ }^{85}$, y telefónicamente transmite de forma reservada y urgente al embajador de España en París el siguiente texto telegráfico para que lo haga llegar a Poincaré, primer ministro francés:

«Es urgente que procure V. E. hacer llegar á conocimiento de Monsieur Poincaré el deseo de Su Majestad y Gobierno de que ordene a Representante francés en Atenas se asocie á gestión Cuerpo diplomático para evitar fusilamiento que parece inminente de Príncipe Andrés. Se estima que abstención Representante francés en Atenas determinaría la de otros colegas y que solo acción colectiva tiene alguna probabilidad de éxito» ${ }^{86}$.

El mismo día 1 se comunica al embajador en Atenas la actividad desplegada y se le informa de que «se están buscando antecedentes respecto si se logró algún indulto de súbditos griegos durante guerra», pero que de momento no se ha encontrado ningún caso $^{87}$, y el día 2 se

${ }^{84}$ Telegrama núm. 19, cifrado clave sin número, 1 de diciembre de 1922, del Ministerio de Estado de España al embajador en Atenas (AMAE, Correspondencia [Grecia], leg.1605). ${ }^{85}$ Telegrama núm. 1, cifrado clave sin número, 1 de diciembre de 1922, del Ministerio de

Estado de España a Francisco Reynoso en Lausana (AMAE, Correspondencia [Grecia], leg.1605).

${ }^{86}$ Telegrama núm. 539, transmitido por teléfono, 1 de diciembre de 1922, del Ministerio de Estado de España al embajador en París (AMAE, Correspondencia [Grecia], leg.1605). ${ }^{87}$ Telegrama núm. 20, cifrado clave número 239, 1 de diciembre de 1922, del Ministerio de Estado de España al embajador en Atenas (AMAE, Correspondencia [Grecia], leg.1605). 
le comunica que Poincaré ha dado orden a su embajador para unirse a la gestión diplomática citada ${ }^{88}$.

El embajador en Atenas intentó poner en práctica rápidamente las órdenes recibidas desde Madrid, pero únicamente pudo entrevistarse con el director de Política, quien se ofreció a hacer llegar personalmente al presidente del Consejo los deseos del rey de España ${ }^{89}$. De la entrevista con éste sacó la impresión de que no había "peligro inminente" y de que «siempre hay temor de que intervención extrajera pueda precipitar acontecimientos». De forma muy confidencial, también informó de que la reina Olga se había entrevistado esa misma tarde en París con el presidente de la República y presidente del Consejo.

La diligente actividad del embajador en Atenas, sus estimaciones y la prudencia observada no impresionaron en absoluto al Ministerio de Estado español, porque el día 2 le enviaron un nuevo telegrama en el que se le instaba, porque se "estima urgentísimo", a que realizara «inmediatamente la gestión especial en nombre de Su Majestad» que se le había encargado en el telegrama número $19^{90}$. Al embajador español debió de impresionarle la reiteración de la urgencia para que cumpliera la orden del Ministerio, porque ese mismo día 2 transmitió telefónicamente una nota de carácter oficioso, que publicó el diario Le Temps, en la que se indicaba que el proceso al príncipe Andrés se ha adelantado en cuarenta y ocho horas, se recuerda la alianza familiar de éste con las casas reales de Inglaterra y España y se pidía que los representantes en Atenas de la Entente -Francia, Inglaterra y Rusia- tuvieran la libertad para escoger «el momento y la modalidad de su intervención $»^{91}$.

${ }^{88}$ Telegrama núm. 21, cifrado clave número 239, 1 de diciembre de 1922, del Ministerio de Estado de España al embajador en Atenas (AMAE, Correspondencia [Grecia], leg.1605). ${ }^{89}$ Telegrama núm. 887, cifrado clave número 301, 1 de diciembre de 1922, del embajador en Atenas al Ministerio de Estado de España (AMAE, Correspondencia [Grecia], leg.1605).

${ }^{90}$ Telegrama núm. 22, cifrado clave número 239, 2 de diciembre de 1922, del Ministerio de Estado de España al embajador en Atenas (AMAE, Correspondencia [Grecia], leg.1605). ${ }^{91}$ Telegrama sin número, transmitido por teléfono, 2 de diciembre de 1922, del embajador en Atenas al Ministerio de Estado de España (AMAE, Correspondencia [Grecia], leg.1605). 
Ese mismo día envió dos telegramas más ${ }^{92}$. En el primero anunciaba que sería recibido por el presidente del Consejo de Ministros esa misma tarde, que la visita la haría en calidad de "gentilhombre (de) cámara”, que invocaría los servicios prestados a los griegos durante la guerra, que el rey griego no había tenido intervención ninguna en las sentencias a muerte de los responsables de Desastre de Asia, que una sentencia capital del príncipe le obligaría a marcharse -se refiere al Rey- y, en otro orden de cosas, que creía que las gestiones del enviado británico puedían perjudicar las suyas. Sin embargo, el diario El Sol había publicado el día 1 de diciembre una escueta nota en la que ponía de relieve que en Londres se temía que su influencia no fuera suficiente para proteger al príncipe Andrés y que el sumario había pasado a dictamen del Gobierno ${ }^{93}$. Ese mismo día también publicó una brevísima reseña biográfica del príncipe.

En el segundo telegrama, número 31, enviado tras la entrevista, comunicó que el presidente del Consejo le había prometido hacer cuanto pudiera para que los deseos del rey de España fueran atendidos y alertó de su temor de que no renunciaran a la "ceremonia de degradación militar". La gestión estuvo a punto de resultar un fracaso debido a una nota del diario $A B C$ que informaba de que se había dado orden desde el Ministerio de Estado al embajador para que tomara la iniciativa y comenzara una acción colectiva a favor del príncipe Andrés ${ }^{94}$.

El día 4 el embajador de España en Atenas transmitió al Ministerio de Estado el texto que le había proporcionado el mariscal de la Corte de Jorge II.

92 Telegramas núms. 30 y 31, cifrados clave 239, 2 de diciembre de 1922, del embajador en Atenas al ministro de Estado de España (AMAE, Correspondencia [Grecia], leg.1605). Lo dicho en ellos se reitera en el despacho núm. 98 del embajador de España en Atenas, de 2 de diciembre, para el ministro de Estado de España. Para la representación de los interese griegos en Turquía ver la nota 9.

${ }^{93}$ El Sol, 1 de diciembre de 1922, pág. 5: «Índice de noticias y "sumario contra el Príncipe Andrés"». [Fabra].

${ }^{94}$ Despacho núm. 99 del embajador de España en Atenas, 5 de diciembre de 1922, para el ministro de Estado de España (AMAE, Correspondencia [Grecia], leg.1605). 
"Querido primo: Profundamente conmovido por cuanto habéis hecho por mi familia, especialmente por mi tío, tengo empeño expresar manera muy particular la expresión de mi más profundo agradecimiento. JORGE II». ${ }^{95}$

\subsection{Otros intervinientes. Elefcerios Venizelos.}

El señor Reynoso, delegado español en Lausana, comunicó al Ministerio de Estado español, mediante telegrama, su entrevista con Venizelos, delegado griego en la Conferencia de Lausana ${ }^{96}$. Según el contenido del telegrama, Venizelos, motu proprio, había telegrafiado al Gobierno de Atenas sobre el príncipe Andrés «encareciendo con el mayor interés, que (el Príncipe) no fuera condenado más que á destierro y que se evitase el acto de la degradación» aunque reconoce, en palabras de Venizelos, que por ser militar y no obedecer órdenes superiores "pudiera haber incurrido en pena severa». Venizelos también habría recomendado al Gobierno que los culpables fueran juzgados por "tribunales ordinarios de justicia, menos intransigentes» que los militares. Durante la entrevista Venizelos habría expresado su convencimiento de que su petición sería escuchada y tenía "la seguridad moral" de que el príncipe no sufriría igual suerte que los responsables del desastre. También añadiría que «Su Majestad, el Rey de España, podía comunicar libremente con el de Grecia». De este mismo telegrama de Reynoso se hace eco la prensa del día, que informa de que «igual gestión cerca de Mr. Venizelos ha sido encargado el Nuncio de Su Santidad». Un telegrama de Venizelos al Comité Revolucionario dice «que la Gran Bretaña ya no es de ninguna utilidad a Grecia» y aconseja que la política griega se oriente en adelante hacia Francia ${ }^{97}$.

\footnotetext{
95 Telegramas núm. 33, 3 de diciembre de 1922, del embajador de España en Atenas al ministro de Estado de España (AMAE, Correspondencia [Grecia], leg.1605)..

${ }^{96}$ Telegrama núm. 4, cifrado clave número 265, 2 de diciembre de 1922, de Reynoso, delegado en Lausana, al Ministerio de Estado de España (AMAE, Correspondencia [Grecia], leg.1605).

${ }^{97}$ El Sol, 15 de diciembre de 1922, pág.5: «Nueva orientación de Grecia» [Radio].
} 


\subsection{Actitud de Francia}

Francia intervino en el proceso tanto por petición de España -petición del embajador español en París a Poincaré para que ordenara a su representante en Atenas que se asociara a la gestión del cuerpo diplomático para evitar el fusilamiento del príncipe Andrés ${ }^{98}$, como por la petición de la reina Olga (reina consorte de Grecia 1867-1913, Gran Duquesa de Rusia, hija del Gran Duque Constantino de Rusia, segundo hijo del zar Nicolás I de Rusia, y de la princesa Alejandra de Sajonia-Altenburg y, sobre todo, madre del príncipe Andrés). El embajador de España en París, José Quiñones, relata la conversación que tuvo con Poincaré ${ }^{99}$ e informó al Ministerio de Estado de los puntos siguientes (sólo citaré aquellos aspectos que son novedosos respecto de lo relatado por el embajador de España en Atenas): a) el Gobierno inglés, preocupado por el príncipe, ha enviado en misión secreta a su antiguo agregado militar en Grecia, comandante Talbot. Éste se ha entrevistado con Mr. De Narcilly, embajador francés, y le ha comentado que «sería muy difícil salvar la vida del Príncipe», a lo que el francés le contesto que el Gobierno griego procuraba «hacer chantaje a los ingleses para que restablezcan la normalidad de las relaciones diplomáticas» y al tiempo, al ser un gobierno con sólo militares, «desea imponerse por el terror con el pretexto de restablecer la disciplina»: b) ambos opinan que una intervención colectiva podría precipitar los acontecimientos, y el francés sugiere que «sería eficaz una intervención separada y directa de España que, encargada en Turquía durante la guerra de los intereses griegos, habrá tenido ocasión de prestar servicio a éstos» (i.e. los griegos); c) que la intervención de España sería más prudente por tratarse de potencia a la que no cabría reprochar que hacía presión sobre Grecia, puesto que no tiene intereses allí.

Tanto el embajador español en Atenas como los de Rusia y Rumanía opinaban que, en caso de intentar una acción diplomática colectiva a

\footnotetext{
${ }^{98}$ Telegrama núm. 539, transmitido por teléfono, 1 de diciembre de 1922, del Ministerio de Estado de España al embajador en París (AMAE, Correspondencia [Grecia], leg.1605).

${ }_{99}$ Telegrama núm. 891, cifrado clave 301, 2 de diciembre de 1922, del embajador de España en París al ministro de Estado de España (AMAE, Correspondencia [Grecia], leg.1605).
} 
favor del príncipe Andrés, ésta debía contar con la participación de Francia, porque su abstención «ocasionaría la de otros colegas como Bélgica, Serbia, Polonia y Brasil por lo menos ${ }^{100}$.

\subsection{Actitud de Inglaterra.}

Inglaterra guiada por su intención de mantener sus intereses políticos y comerciales en la zona, manifestó su apoyo a Grecia en el intento de ésta de recuperar la antigua Jonia, pero siempre a condición de que los gobiernos y el monarca griegos fueran claramente anglófilos. Al perder las elecciones Venizelos y cambiar la situación política griega con la vuelta del rey Constantino, Inglaterra suprimió la ayuda prometida y, tras el golpe de Estado en Atenas, se comportó con Grecia como si ésta fuera una colonia, en palabras del Venizelos, lo que no benefició en nada a los procesados. Respecto del príncipe Andrés, envió en misión secreta a su antiguo agregado militar en Grecia, comandante Talbot. Tan secreta fue su misión que, según comentó al embajador español Vallín ${ }^{101}$, ni siquiera lo había comunicado a su embajada. No obstante, el embajador español opinaba que la intervención del inglés podría perjudicar las suyas.

\section{4.- Consideraciones finales}

El embajador español apenas da opinión propia sobre el juicio a los ministros y generales que aquí tratamos. En realidad, lo que hizo fue seguir las iniciativas que otros colegas suyos emprendieron, y relatar las opiniones de personas que le merecieron credibilidad o creyó bien informadas. Por tanto, la posición de España respecto del juicio a los responsables del Desastre de Asia, fue seguidista respecto de lo que hacían otras embajadas y en ningún momento tomó iniciativa alguna. Esta falta de posicionamiento político no es de extrañar, porque concuerda plenamente con lo dicho por el ministro del ramo

\footnotetext{
${ }^{100}$ Despacho núm. 98 del embajador de España en Atenas, 2 de diciembre de 1922, para el ministro de Estado de España (AMAE, Correspondencia [Grecia], leg.1605).

101 Telegrama núm. 30, cifrado clave 239, 2 de diciembre de 1922, del embajador en Atenas al ministro de Estado de España (AMAE, Correspondencia [Grecia], leg.1605).
} 
y expuesto en la introducción, es decir, que lo natural era «marchar de acuerdo con Inglaterra y Francia» y, cuando no hubiera acuerdo entre ellas, apartarnos para que no nos alcanzaran las consecuencias, lo que en realidad muestra una falta total de política exterior en la zona.

Esto contrasta con la actividad desplegada en relación con el juicio del príncipe Andrés, respecto del cual hay una posición muy activa tanto del embajador en Atenas, mediante entrevistas, como del Ministerio de Estado, ordenando contactos al representante en Lausana y al embajador en París. Incluso el embajador en Atenas pone en duda la eficacia de las gestiones de Londres. El Ministerio de Estado estuvo en contacto con la embajada de París para conocer la actitud del Gobierno francés ${ }^{102}$ y con la embajada de los Países Bajos en Madrid, porque el ministro holandés quería conocer la opinión de España ${ }^{103}$, y también con Londres.

La nota que el embajador británico en Atenas envió al Gobierno revolucionario griego con motivo de la ejecución de los responsables políticos y militares del Desastre de Asia Menor, que fue calificada por el embajador español de "muy enérgica", y la actitud del Ministerio de Estado al contactar con el homónimo francés en lugar de hacerlo con el inglés en el caso del príncipe Andrés, se ve avalada por el telegrama del embajador español en Londres, según el cual ${ }^{104}$ : a) los periódicos allegados al Gobierno y algunos liberales habían censurado como grave error diplomático la actitud de Inglaterra hacia la ejecución al estimar que dicha intervención había excedido «a la corrección que debe conservarse respecto a asuntos internos de otras naciones»; b) al tiempo que estigmatizaban la ejecución, advertían de la delicada situación de Grecia en la conferencia de Lausana, porque Inglaterra constituía su único apoyo; c) «este criterio refleja el del público británico en general».

\footnotetext{
102 Telegrama núm. 536, cifrado clave 221, 30 de noviembre de 1922. del ministro de Estado de España al embajador en París (AMAE, Correspondencia [Grecia], leg.1605).

103 Telegrama núm. 126, cifrado clave 301, 30 de noviembre de 1922, del embajador en La Haya al ministro de Estado de España (AMAE, Correspondencia [Grecia], leg.1605).

104 Telegrama núm. 543, cifrado clave 241, 5 de diciembre de 1922, del embajador en Londres al ministro de Estado de España (AMAE, Correspondencia [Grecia], leg.1605).
} 
En esos momentos el Gobierno británico no debía tener muy clara su posición porque, unos minutos más tarde el mismo embajador en Londres comunicó al ministro que el subsecretario de Asuntos Exteriores no había contestado en el Parlamento ${ }^{105}$ a preguntas sobre correspondencia entre Gúnaris y la legación británica, pero había dicho que no tenía noticias de que otras legaciones se hubieran retirado de Atenas. Argumentó, apoyando esa posición, que el encargado de negocios de Italia había recibido orden «de abstenerse de todas relaciones con el Gobierno griego» y finalmente dijo que el Gobierno no había decidido aún retirar la Misión naval.

El embajador español en Londres también informó de que el presidente del Consejo se había negado a discutir sobre «la presunta incitación por parte del anterior Gobierno británico a los griegos para internarse en Asia Menor». Al parecer el periódico Le Matin de París había publicado «documentos secretos relativos a política británica en Grecia» que podían implicar al Gobierno británico. Todo esto se expone con un lenguaje puramente descriptivo sin valoración alguna y sin que haya contestación del Gobierno de España, que aparece como mero espectador.

El príncipe Andrés expresó públicamente su gratitud en una entrevista del Daily Express en la que declaró «que debe su vida a la intervención del Papa, Su Majestad el Rey de España y su Majestad Británica» ${ }^{106}$. En ella pondera el hecho de que el Gobierno británico enviara «un mensajero especial para que interviniera cerca del Comité Revolucionario», que según el embajador español más bien entorpeció sus gestiones. Al parecer, círculos oficiales británicos "desmintieron" (o, mejor dicho, mintieron al desmentir) tal noticia sobre el enviado especial, puesto que tenemos constancia a través del embajador español de que tal enviado existió.

\footnotetext{
${ }^{105}$ Telegrama núm. 553, cifrado clave 241, 5 de diciembre de 1922, del embajador en Londres al ministro de Estado de España (AMAE, Correspondencia [Grecia], leg.1605).

${ }^{106}$ Despacho núm. 1365 del embajador de España en Londres, de 12 de diciembre de 1922, para el ministro de Estado de España (AMAE, Correspondencia [Grecia], leg.1605).
} 
También Jorge II agradeció al Gobierno español su intervención a favor del príncipe Andrés ${ }^{107}$. Pero el Gobierno español debía tener alguna reticencia en reconocerlo, porque el embajador en Atenas contestó a un telegrama del Ministerio explicando que, por ser el más antiguo, sus colegas estaban esperando que tomara la «iniciativa en beneficio de la monarquía» ${ }^{108}$, y unos días después, en otro telegrama, reiteraba que el «retraso sería interpretado (como una) vacilación (en) reconocer $(\mathrm{al})$ rey actual» ${ }^{109}$.

El Gobierno de Atenas anunció que por razones económicas cerraba varias legaciones en el extranjero, entre ellas la de Madrid ${ }^{110}$. El 26 de diciembre, el mismo día que el nuevo embajador de España en Atenas presentaba sus credenciales ${ }^{111}$, se anuncia que ha sido suprimida la Legación de Grecia en Madrid. Como consecuencia del anuncio de supresión, el ministro de Estado español encargó al embajador en Grecia que transmitiera al gobierno griego «que Gobierno (de) S.M. vería con gusto continuase legación griega aquí (en Madrid) que, precisamente cuando nos hemos hecho cargo protección intereses griegos en Turquía, puede revestir especial utilidad $»^{112}$. La gestión debió dar buen resultado, porque el mismo embajador comunica al ministro el día 30 que, confidencialmente,

${ }^{107}$ Telegrama núm. 34, cifrado clave 239, 5 de diciembre de 1922, del embajador español en Atenas al ministro de Estado de España (AMAE, Correspondencia [Grecia], leg.1605). El embajador transcribe entrecomilladas las que parecen ser palabras textuales del rey, muy elogiosas de su labor: por «tener aquí un representante á cuyo tacto y habilidad cumplimiento instrucciones S.M. se debe éxito alcanzado».

108 Telegrama núm. 30, cifrado clave 239, 5 de diciembre de 1922, del embajador español en Atenas al ministro de Estado de España (AMAE, Correspondencia [Grecia], leg.1605).

109 Telegrama núm. 35, cifrado clave 239, 12 de diciembre de 1922, del embajador español en Atenas al ministro de Estado de España (AMAE, Correspondencia [Grecia], leg.1605).

${ }^{110}$ Telegrama núm. 21 cifrado clave 301, 30 de diciembre de 1922, del embajador español en Roma al ministro de Estado de España (AMAE, Correspondencia [Grecia], leg.1605); cf. El Sol, 20 de diciembre de 1922, pág.5: «Índice de noticias».

${ }^{111} \mathrm{El}$ Sol, 26 de diciembre de 1922, pág.5: «Legación suprimida» y «Presentación de credenciales» [Fabra].

112 Telegrama núm. 50, 26 de diciembre de 1922, del ministro de Estado de España al embajador español en Atenas (AMAE, Correspondencia [Grecia], leg.1605). 
sabía "que se proponían restablecerla» ${ }^{113}$. El día 31 el diario El Sol anunciaba que no se suprimía y que el embajador permanecía en calidad de encargado de negocios ${ }^{114}$.

El alcance de la protección de intereses griegos en Turquía por parte de España excede a este trabajo. El diario El Sol anunció el día 17 de diciembre que el alto comisario griego (de Constantinopla) había sido suprimido y que «la protección de los súbditos helenos residentes en esa capital ha sido confiada al representante de España» ${ }^{115}$. En fecha muy próxima a la del último telegrama comienzan las conversaciones sobre la forma de trasladar la correspondencia oficial al Consulado General griego en Constantinopla a través de la embajada española ${ }^{116}$.

Todo parece indicar que Inglaterra alentó y prometió ayudar a Grecia a recuperar los territorios de la antigua Jonia en detrimento del Imperio Turco por razones comerciales, pero tal promesa no se cumplió por el regreso a Grecia del rey Constantino, por el que no tenía ninguna simpatía al haberse mostrado durante la Guerra Mundial partidario de Alemania. Una vez que Elefcérios Venizelos perdió las elecciones debido al hartazgo de la población por las guerras y a la deshonrosa ingerencia que debió suponer para el pueblo griego o, al menos, para una parte importante de él, el desembarco de tropas inglesas en Pireo para garantizar la neutralidad del gobierno del rey Constantino, éste regresó tras un referéndum, que fue calificado de fraudulento. Los nuevos responsables políticos y militares griegos no mostraron el mismo celo por ampliar el territorio que había trenido Venizelos, cometieron el error de remover a los jefes militares del frente de Asia Menor por otros más próximos ideológicamente y perdieron el apoyo de Inglaterra, como ésta ya había anunciado

\footnotetext{
${ }^{113}$ Telegrama núm. 39, cifrado clave 230, 30 de diciembre de 1922, del embajador español en Atenas al ministro de Estado de España (AMAE, Correspondencia [Grecia], leg.1605). ${ }^{114}$ El Sol, 31 de diciembre de 1922, pág.1: «No se suprime» [Radio].

${ }^{115}$ El Sol, 17 de diciembre de 1922, pág.5: «La cuestión de Oriente» [Fabra].

${ }^{116}$ Carta del embajador en Atenas a la Subsecretaría del Ministerio de Estado, 1 de febrero de 1923, en respuesta a una R.O. de 21 de enero del mismo año (AMAE, Correspondencia [Grecia], leg.1605).
} 
en caso de regreso de Constantino. Cuando se produjo el Golpe de Estado y el Comité Revolucionario decidió juzgar a los responsables del Desastre de Asia Menor, Inglaterra volvió a intervenir en la política interna griega con la nota que el embajador español calificó de "muy enérgica" y que, unánimemente, fue calificada de error; nota e intervención que le hicieron decir a Venizelos que «Grecia era un país libre y no una colonia inglesa».

Finalmente, ninguna intervención exterior consiguió piedad para los responsables del Desastre, e Inglaterra se apresuró a repartir la responsabilidad del fracaso de su política con Grecia incluyendo a Venizelos, al que comenzaron a tratar fríamente en Lausana, y a cambiar su interlocutor en Atenas. Aún así, el príncipe Andrés se salvó de la muerte.

Respecto de la prensa citada, hay que señalar los diferentes posicionamientos que manifiestan, en consonancia con sus posiciones ideológicas de partida. Así, el diario $A B C$ o bien informa sin aparente posición ideológica o manifiesta su creencia de que la sentencia a los Seis estaba prevista desde la inauguración del proceso, quitando con ello, sin decirlo, legitimidad al juicio. Los diarios El Sol y La Voz, del mismo grupo ideológico liberal y regeneracionista, comparan el desastre de Grecia en Asia Menor con el de España en Annual y ponen de manifiesto la distinta valoración que se hace, en ambos países, de sus desastres particulares, y ponen a Grecia como ejemplo de lo que se debería hacer en España. El Socialista, por su parte, pone de manifiesto que los enfrentamientos de Grecia y Turquía en Asia Menor son el resultado de los enfrentamientos de las burguesías de las potencias europeas, apunta al rey de España como responsable del desastre de Annual porque él elige a los que le rodean, y echa de menos en España la vitalidad del pueblo griego que, ante una situación similar a la española, provocó una revolución. 


\section{ANEXOS}

\section{1.- Reyes de Grecia}

Jorge I [Guillermo de Dinamarca, segundo hijo del rey Cristian IX de la casa de Glücksburg]. Reinado: 1863-1913. Casado con Olga de Rusia.

Constantino I. Primer reinado: 1913-1917. Segundo reinado 19201922. Casado con Sofía de Prusia.

Alejandro I. Reinado: 1917-1920.

Jorge II. Primer reinado: 1922-1923. Segundo reinado: 1935-1947.

2.- Presidentes de Gobierno de Grecia. (En negrita los citados en el texto)

Dimitrios Gúnaris [8 de abril de 1921 / 16 de mayo de 1922]

Nicólaos Stratós [16 de mayo de 1922 / 22 de mayo de 1922]

Petros Protopapadakis [22 de mayo de 1922 / 10 de septiembre de 1922]

Nicólaos Triandafílakos [10 de septiembre de 1922 / 29 de septiembre de 1922]

Anastasios Jaralambís [29 de septiembre de 1922 / 30 de septiembre de 1922]

Sotirios G. Crokidás [30 de septiembre de 1922 / 27 de noviembre de 1922

Stilianós Gonatás [27 de noviembre de 1922 / 24 de enero de1924]

\section{3.- Hechos históricos relevantes.}

1919, mayo: desembarco del ejército griego en Esmirna.

1920, agosto: tratado de Sèvres, que crea la Grecia de «los dos continentes y los cinco mares»

Octubre: muerte del rey Alejandro.

Noviembre: Venizelos pierde las elecciones y abandona Grecia.

Diciembre: Referéndum fraudulento favorable al regreso del rey

Constantino.

1921, agosto: batalla del río Sangario, que supone la detención del avance griego sobre Ankara. 
1922, agosto-septiembre: retirada del ejército griego de Asia Menor.

11 de septiembre: Golpe de estado dirigido por el coronel Plastiras.

19 de octubre: constitución de la comisión de investigación del

Desastre.

22 de noviembre: demostraciones populares de adhesión a los fines de la revolución.

24 de noviembre: el diario El Sol informa de un complot contrarrevolucionario.

27 de noviembre: dimite el Gobierno de Sotirios Crokidás. 28 de noviembre: el Tribunal dicta sentencia de muerte y se ejecuta a los enjuiciados.

3 de diciembre: el Tribunal dicta sentencia sobre el príncipe Andrés, que embarca hacia Brindisi. 